Y

спешный опыт лечения первичной кожной анапластической крупноклеточной лимфомы, протекающей с распространенным поражением кожного покрова и легочной ткани

Чернова Н. Г. ${ }^{1, \star}$, Бадмажапова Д. С. ${ }^{1}$, Ковригина А. М. ${ }^{1}$, Карамова А. Э. ${ }^{2}$, Воронцова А. А. ${ }^{2}$, Синицына М. Н. ${ }^{1}$, Сидорова Ю. В. ${ }^{1}$, Гребенюк Л. А. ${ }^{1}$, Несредова М. А. ${ }^{2}$, Знаменская Л. Ф. ${ }^{2}$, Звонков Е. Е. ${ }^{1}$, Савченко В. Г. ${ }^{1}$

\footnotetext{
${ }^{1}$ Национальный медицинский исследовательский центр гематологии Министерства здравоохранения Российской Федерации 125167, Российская Федерация, г. Москва, Новый Зыковский пр., д. 4

${ }^{2}$ Государственный научный центр дерматовенерологии и косметологии Министерства здравоохранения Российской Федерации 107076, Российская Федерация, г. Москва, ул. Короленко, д. 3, стр. 6
}

Цель: демонстрация успешного опыта лечения первичной кожной анапластической крупноклеточной лимфромы (пкАККЛ), протекающей с распространенным поражением кожного покрова и легочной ткани.

Материалы и методы. Для верификации диагноза у больного с тремя видами кожных элементов (пятно, тонкая бляшка с изъязвлением и без него) проводилась диффреренциальная диагностика между язвенно-гангренозной пиодермией, пкАККЛ, крупноклеточной трансфоормацией грибовидного микоза и вторичным поражением кожи при нодальной AKKЛ, ALK-. Проведенный комплекс исследований, включающий гистологическое, иммуногистохимическое, цитогенетическое исследования биоптата опухоли кожи, позволил верифрицировать диагноз пкАККЛ. Для лечения больного была применена интенсивная индукционная химиотерапия с последующей высокодозной консолидацией и аутологичной трансплантацией гемопоэтических стволовых клеток.

Результаты. Выбранная тактика лечения позволила достигнуть продолжительной полной ремиссии заболевания у больного из группы неблагоприятного прогноза.

Заключение. Представлены алгоритм диффференциальной диагностики и определение тактики лечения больного первичной кожной анапластической крупноклеточной лимфомой с распространенным поражением кожного покрова и экстрадермальными очагами.

Ключевые слова: первичная кожная анапластическая крупноклеточная лимфома, поражение легких, высокодозная химиотерапия, аутологичная трансплантация гемопоэтических стволовых клеток

Конфрликт интересов: авторы заявляют об отсутствии потенциального конфликта интересов, требующего раскрытия в данной статье.

Для цитирования: Чернова Н. Г., Бадмажапова Д. С., Ковригина А. М., Карамова А. Э., Воронцова А. А., Синицына М. Н., Сидорова Ю. В., Гребенюк Л. А., Нефедова М. А., Знаменская Л. Ф., Звонков Е. Е., Савченко В. Г. Успешный опыт лечения первичной кожной анапластической крупноклеточной лимфомы, протекающей с распространенным поражением кожного покрова и легочной ткани. Вестник дерматологии и венерологии. 2018;94(4):30-42. https://doi.org/10.25208/0042-4609-2018-94-4-30-42 


\title{
Ouccessful experience in treating primary cutaneous anaplastic large cell lymphoma occuring with common lesions of the skin and lung tissue
}

\author{
Natalia G. Chernova ${ }^{1, *}$, Darima S. Badmazhapova ${ }^{1}$, Alla M. Kovrigina', Arfenya E. Karamova², Anastasia A. Vorontsova², \\ Marina N. Sinitcina', Yulia V. Sidorova', Lyubov A. Grebenyuk', Maria A. Nefedova², Ludmila F. Znamenskaya², \\ Evheny E. Zvonkov' ${ }^{1}$, Valery G. Savchenko ${ }^{1}$
}

\footnotetext{
${ }^{1}$ National Research Center for Hematology

Zykovsky Novy proezd, 4, Moscow, 125167, Russian Federation

2 State Scientific Center of Dermatovenereology and Cosmetology

Korolenko str., 3, building 6, 107076, Moscow, Russian Federation
}

\begin{abstract}
The aim of the study is to present a successful case in treating primary cutaneous anaplastic large cell lymphoma (PCALCL) occurring with common lesions of the skin and lung tissue.

Materials and methods. For the verification of the diagnosis in a patient with three types of skin elements (spot, thin plaque with and without ulceration), differential diagnosis was performed between ulcerative pyoderma gangrenosum, PCALCL, large-cell transformation of mycosis fungoides, and secondary skin lesions under the nodal ALK-negtaive ALCL. A complex of studies, including histological, immunohistochemical, cytogenetic studies of skin tumor biopsy, allowed the verification of the PCALCL diagnosis. For the treatment of the patient, intensive induction chemotherapy was used followed by high-dose consolidation and autologous transplantation of hematopoietic stem cells.

Results. The selected treatment tactics allowed a long-term complete remission of the disease to be achieved in a patient from the poor prognosis group.

Conclusion. An algorithm for the differential diagnosis and tactics of treating is presented for a patient with primary anaplastic large cell lymphoma with a widespread skin lesion and extradermal foci.
\end{abstract}

Keywords: primary cutaneous anaplastic large cell lymphoma, lung damage, high-dose chemotherapy, autologous transplantation of hematopoietic stem cells

Conflict of interest: the authors state that there is no potential conflict of interest requiring disclosure in this article.

For citation: Chernova N. G., Badmazhapova D S., Kovrigina A M., Karamova A E., Vorontsova A A., Sinitcina M N., Sidorova Yu. V., Grebenyuk L. A., Nefedova M. A., Znamenskaya L. F., Zvonkov E. E., Savchenko V. G. Successful experience in treating primary cutaneous anaplastic large cell lymphoma occuring with common lesions of the skin and lung tissue. Vestnik Dermatologii i Venerologii. 2018;94(4):30-42. https://doi.org/10.25208/0042-4609-2018-94-4-30-42 


\section{Список сокращений}

AKKЛ, ALK - анапластическая крупноклеточная ALK-негативная лимфома

ГСК - гемопоэтические стволовые клетки

пкАККЛ - первичная кожная анапластическая крупноклеточная лимфома

ALK - киназа анапластических лимфом

СЕАМ - ломустин, этопозид, цитарабин, мелфралан

СНОР - циклофросфрамид, доксорубицин, винкрис-

тин, преднизолон

FISH - fluorescence in situ hybridization

NHL-BFM-90, блок A - дексаметазон, ифоссрамид, метотрексат, доксорубицин, винкристин, цитарабин, этопозид, месна, кальция фолинат

\section{Введение}

Первичная кожная анапластическая крупноклеточная лимфома (пкАККЛ) составляет $20 \%$ от всех Т-клеточных лимсром кожи и 1,7\% от всех зрелых Т-клеточных лимфом [1]. ПкАККЛ занимает второе место среди Тклеточных лимфом кожи после грибовидного микоза [2]. Заболевание может возникнуть в любом возрасте, но чаще диагностируется в возрасте около 60 лет [3]. Мужчины заболевают в 2-3 раза чаще женщин [3-5]. Первичная кожная анапластическая крупноклеточная лимфома характеризуется появлением единичных или сгруппированных нескольких быстро растущих новообразований, часть из которых может изъязвляться. В большинстве случаев опухолевые очаги располагаются на голове, шее и конечностях [3]. Приблизительно у 80 \% больных наблюдается солитарный характер расположения кожных элементов, тогда как в остальных 20 \% случаев отмечается диссеминация опухолевого процесса с поражением 2-3 различных анатомических зон [4, 6]. Интересно, что у 10-42 \% больных на начальных этапах заболевания наблюдается полная или частичная спонтанная регрессия опухолевых очагов. Вместе с тем без проведения противоопухолевого воздействия полная эрадикация опухоли невозможна, а рецидив заболевания неизбежен [4, 7]. Вовлечение экстрадермальных структур при пкАККЛ происходит крайне редко, как правило, наблюдается поражение регионарных лимфатических узлов, внекожная диссеминация заболевания определяется у 5-10\% больных [4, 8]. Частота специфиического поражения костного мозга при пкАККЛ не превышает $5 \%$ случаев заболевания [9].

Диагноз пКАККЛ устанавливается на основании морфологического исследования биоптата кожи. При гистологическом исследовании выявляется плотный лимфоодный инсрильтрат из крупных клеток, располагающийся в дерме и/или гиподерме, эпидермотропизм отсутствует или слабо выражен [2]. Клетки лимфоидного инорильтрата в $75 \%$ случаев характеризуются «классической» анаплазированной морфологией: подковообразная или почкообразная форма крупных лимфоиддных клеток с эксцентрично расположенным ядром, эозинофильное окрашивание в парануклеарной области цитоплазмы - зоне аппарата Гольджи [2]. В остальных 20-25 \% случаев пкАККЛ наблюдается плеоморфная или иммунобластная морфологическая картина, иногда обнаруживается обилие нейтрофильных и эозинофильных гранулоцитов, что может затруднять верификацию Т-клеточной лимфомы кожи $[4,6$, 10]. Характерной особенностью анапластических круп- ноклеточных лимфом, в том числе и пкАККЛ, является яркая практически мономорфная экспрессия антигена CD30: позитивны более 75 \% клеток опухолевого субстрата. Опухолевые клетки при пкАККЛ, как правило, не экспрессируют киназу анапластических лимфом [2]. В большинстве случаев в опухолевых клетках наблюдается вариабельная экспрессия пан-Т-клеточных антигенов CD2, CD4 и CD45RO, активационных маркеров CD25, CD71, HLA-DR, цитотоксических белков (TIA-1, гранзим Виперфорин). Экспрессия других пан-Т-клеточных антигенов (CD3, CD5, CD43 и др.) может быть вариабельной [3, 5, 11-13]. Реаранжировка генов цепей Т-клеточного рецептора определяется приблизительно в 90 \% случаев, однако экспрессия белков Т-клеточного рецептора (TCRbF1) выявляется значительно реже [14]. При пкАККЛ отсутствуют патогномоничные хромосомные аберрации. Наиболее частыми хромосомными аберрациями при пкАККЛ являются амплификация $7 q 31$ и делеции 6q16-21 и $13 q 34[15,16]$. Реаранжировки локуса IRF4-DUSP22 на 6р25.3 выявляются приблизительно в 30 \% случаев [17, 18]. Транслокации с вовлечением локуса гена TP63, ассоциированные с неблагоприятным прогнозом при нодальной анапластической крупноклеточной, ALK-негативной лимфоме (АKKЛ, ALK-), наблюдаются в редких случаях пКАKKЛ с необычным агрессивным течением заболевания [19, 20]. Определение делеций $6 q 21$ и $18 p 11.3$ в дебюте пкАККЛ имеет прогностическое значение, эти хромосомные нарушения выявляются соответственно в 86 и 43 \% случаев рецидивирующего течения пкАККЛ [21].

Несмотря на сходные морфологические черты с нодальными анапластическими крупноклеточными лиморомами, пкАККЛ характеризуется благоприятным клиническим течением и высокой химиочувствительностью. Для лечения пкАККЛ применяется несколько подходов в зависимости от распространенности опухолевого процесса. При солитарном характере расположения опухолевых очагов применяют хирургическое удаление и/или дистанционную лучевую терапию в СОД 40 Гр. При единичных опухолевых элементах, но располагающихся в разных анатомических зонах, проводят терапию малыми дозами метотрексата по 10-25 мг еженедельно. При генерализованном опухолевом процессе и/или наличии экстрадермальных очагов поражения в настоящее время подходы к лечению не определены. В качестве терапии первой линии проводится «золотой стандарт» - программа СНОР. При рефрактерном/ рецидивном течении заболевания применяют аналоги пурина, ретиноиды, интерферон-а, интерлейкин 12 [7]. В последнее время появились единичные сообщения об успешном применении для лечения CD30-позитивных лимфопролифреративных заболеваний брентуксимаб ведотина, являющегося анти-CD30-моноклональным антителом, конъюгированным с монометилауристатином $E[22,23]$. Этот препарат продемонстрировал свою эффрективность и безопасность в лечении больных лимфомой Ходжкина, анапластических крупноклеточных лимфом, в том числе и пкАККЛ [24].

Прогноз пКАККЛ обычно благоприятный, 10-летняя общая выживаемость составляет приблизительно $90 \%[4,25]$. Однако отмечено, что при поражении кожи нижних конечностей прогноз значительно хуже, 5-летняя общая выживаемость не превышает 76 \% [26]. При оценке роли прогностических фракторов пкАККЛ пока- 
зано, что ни анаплазированная морфология опухолевых клеток, ни высокий пролиферативный потенциал Ki67, ни вовлечение регионарных лимфатических узлов не ассоциированы с неблагоприятным прогнозом. Независимыми фракторами прогноза для общей выживаемости являются распространенное поражение кожи конечностей и наличие экстрадермальных очагов поражения [8, 25-28].

Приводим описание алгоритма диагностики и успешного лечения первичной кожной анапластической крупноклеточной лимсомы, протекающей с распространенным поражением кожных покровов и экстрадермальными очагами.

\section{Клинический случай}

Больной М., 38 лет, поступил в ФГБУ «ГНЦДК» Минздрава России в августе 2016 года с жалобами на болезненные высыпания на коже туловища, верхних конечностей, сопровождающиеся зудом. Со слов больного, в декабре 2015 года впервые отметил появление высыпаний, напоминающих «узелки», на коже правой лопаточной области. Через полгода пациент отметил увеличение размеров и изъязвление первого кожного элемента, появление вокруг новых элементов, выступающих над поверхностью кожных покровов на 3-4 мм размерами до 2-3 см в диаметре. При обращении к врачу-дерматовенерологу по месту жительства была проведена диагностическая биопсия кожи. При гистологическом исследовании биоптата изъязвленного кожного элемента данных за опухолевый процесс не было получено. В посевах из изъязвленных кожных элементов очагов были выявлены синегнойная палочка (Pseudomonas aeruginosa) и золотистый стафилококк (Staphylococcus aureus). Установлен диагноз язвенногангренозной пиодермии. Проведенная антибактериальная терапия широкого спектра действия не оказала существенного эффректа на кожный процесс. С июня по август 2016 года отмечалось распространение высыпаний по всей поверхности кожного покрова, в связи с чем пациент был направлен на консультацию в ФГБУ «ГНЦДК» Минздрава России.

Со слов больного, с 10-летнего возраста страдал псориазом, однако медицинская документация, подтверждающая диагноз псориаза и сведения о проводимом лечении, не была предоставлена.

На момент поступления в ФГБУ «ГНЦДК» Минздрава России кожный патологический процесс носил распространенный характер. На коже туловища и конечностей на фоне эритемы, отека и инфильтрации кожи имелись множественные узелковые элементы полушаровидной формы размером от 0,3 до 1 см в диаметре с влажными эрозиями на поверхности ярко-розового цвета, некоторые из них были покрыты серозно-геморрагическими корками. На коже плечелопаточной и поясничной областей отмечались многочисленные эрозивно-язвенные дефекты с плотными возвышающимися над поверхностью кожи валиками по периферии и обильным серозно-гнойным отделяемым, покрытые плотными темно-коричневыми и рыхлыми желтоватогрязного цвета корками (рис. 1 А, Б). Также по всей поверхности кожного покрова наблюдались сливающиеся гиперпигментированные пятна (со слов больного, на местах прежних псориатических высыпаний). При проведении культурального исследования отделяемого из язвенных дефектов обнаружены синегнойная палочка и золотистый стафилококк. На основании клиникоанамнестических данных поставлен предположительный диагноз лимфомы кожи, осложненной вторичной пиодермией.

Для верификации диагноза проведена биопсия участков наиболее иноильтрированных изъязвленных бляшек на коже живота, спины и подмышечной обла-
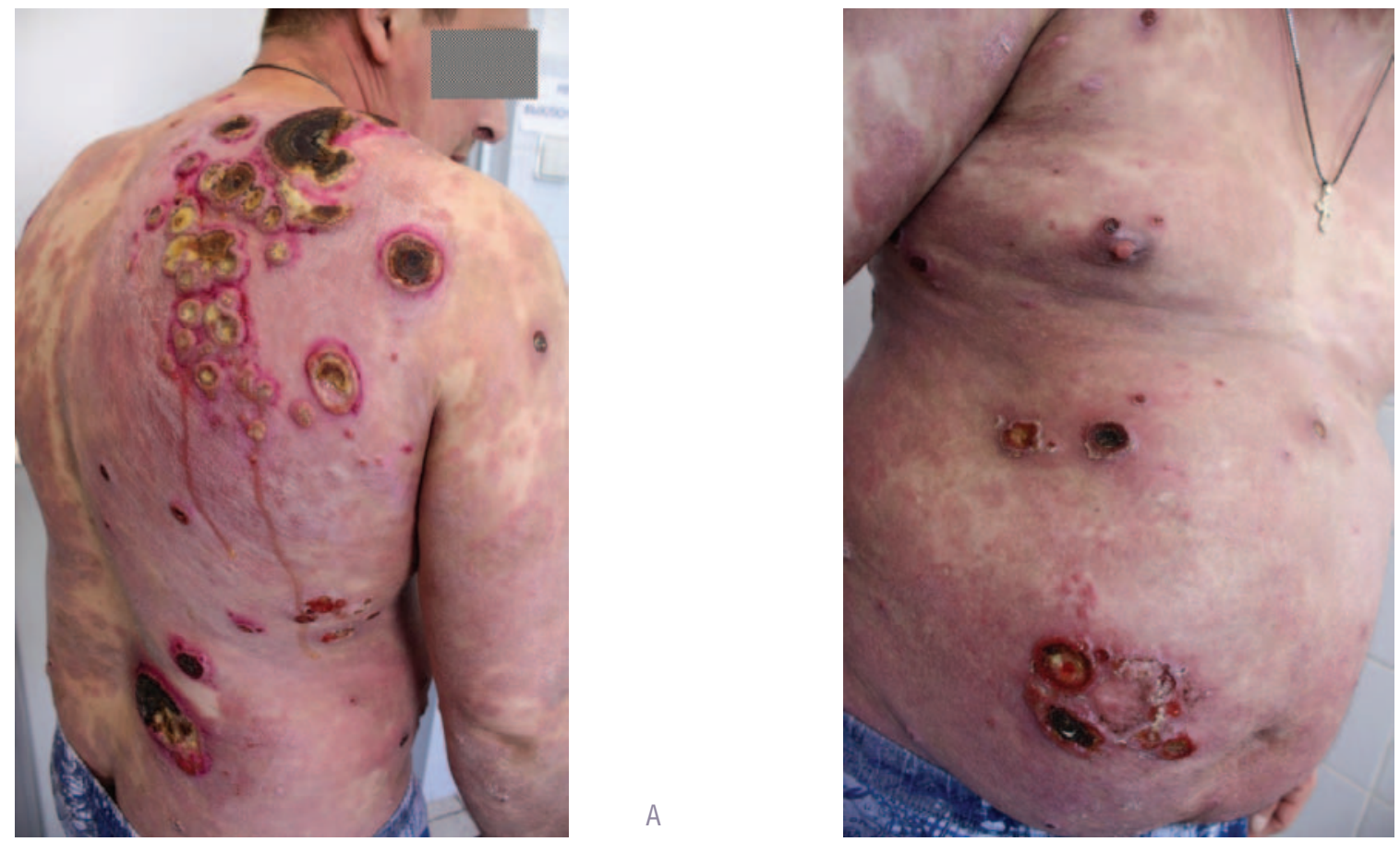
сти. Во всех гистологических препаратах наблюдалась идентичная морорологическая картина. В биоптатах кожи в поверхностных и средних отделах дермы был выявлен плотный инфильтрат из крупных полиморфных лимфоидных клеток с гиперхромными, в том числе церебриформными ядрами, с большим количеством митозов, была отмечена выраженная инфильтрация полиморфными лимфоидными клетками верхних отделов эпидермиса (рис. 2 А, Б). Для подтверждения диагноза и уточнения формы заболевания рекомендовано проведение иммуногистохимического исследования, в связи с чем материал (парафиновые блоки) был направлен в ФГБУ «НМИЦ гематологии». При иммуногистохимическом исследовании большинство крупных анаплазированных лимфоидных клеток экспрессировали антигены CD30 (мембранная, цитоплазматическая, dotlike-реакция), CD3є (мембранная/цитоплазматическая реакция), CD4, TIA-1 (гранулярная цитоплазматическая реакция), Гранзим В (гранулярная цитоплазматическая реакция), индекс пролиферативной активности Кi67 составил 80 \%. Опухолевые клетки не экспрессировали ALK - киназу анапластических лимфом (рис. 3 A-3). Таким образом, при морфологическом исследовании кожи выявлена картина CD30-позитивного Т-клеточного лимфопролиферативного заболевания кожи. Учитывая быстрое прогрессирование опухолевого процесса: появление новых кожных элементов, изъязвление уже существующих, распространение на кожу нижних конечностей, начата терапия малыми дозами метотрексата 30 мг еженедельно, а также антибактериальная терапия. На фоне проведенного лечения наблюдался кратковременный положительный ответ: уменьшение эритемы и отека кожи в очагах поражения; очищение язвенных дефектов от гнойного отделяемого и уплощение валиков по их периферии; частичная эпителизация крупных и полная эпителизация мелких эрозивно-язвенных дефектов (рис. 4 А, Б).

Для определения дальнейшей тактики лечения больной был направлен в ФГБУ «НМИЦ гематологии» Минздрава России.

При поступлении в октябре 2016 г. в гематологическую клинику у больного отмечалось распространенное поражение кожного покрова, сопровождающееся кожным зудом. Несмотря на терапию малыми дозами мето- трексата наблюдалось дальнейшее прогрессирование опухолевого процесса (рис. 5 A-В). Симптомов интоксикации (лихорадка более $38,0^{\circ} \mathrm{C}$, потеря веса, слабость, потливость) не было.

При осмотре на коже больного наблюдалось три типа кожных элементов: гиперпигментированные пятна, тонкие бляшки с изъязвлением и без него. При пальпации выявлен увеличенный аксиллярный лимфатический узел плотной эластической консистенции размерами $2 \times 1,5$ см, размеры других периферических лимфатических узлов не были изменены.

В гемограмме - умеренная анемия (гемоглобин 113 г/л), содержание тромбоцитов $357 \times 10 \%$ л, лейкоцитов - 8,9 × 10\%, СОЭ 58 мм/ч. В лейкоцитарной формуле выявлено увеличение количества палочкоядерных нейтрофилов до $10 \%$, умеренная лимфопения до $17 \%$. Биохимические показатели оставались в пределах референсных значений, активность лактатдегидрогеназы - 339 ед./л (N 208-378).

При ультразвуковом исследовании органов брюшной полости размеры печени, селезенки и висцеральных лимфатических узлов не увеличены. При мультиспиральной компьютерной томографии органов грудной клетки выявлено множественное очаговое поражение легочной ткани обоих легких с максимальным размером очагов до 1 см, очаги имели округлую фрорму с четкими границами (рис. 6 А-B).

С диагностической целью была проведена биопсия кожного элемента (пятно) и трепанобиопсия костного мозга. При морфологическом исследовании биоптата кожи не было получено данных за опухолевый процесс, выявленная морфологическая картина соответствовала неопухолевому дерматозу и не противоречила псориатическому поражению кожи. При морфологическом исследовании костного мозга не было обнаружено специфического поражения. Биопсия подмышечного лимфатического узла не проводилась в связи с изъязвлением кожных покровов в области необходимого хирургического доступа.

Стандартное цитогенетическое исследование клеток костного мозга определило нормальный кариотип. При FISH-исследовании на гистологических срезах биоптата кожи (тонкая бляшка) с локус-специфичным ДНК-зондом LSI ALK Dual Color, Break Apart Rearrangement

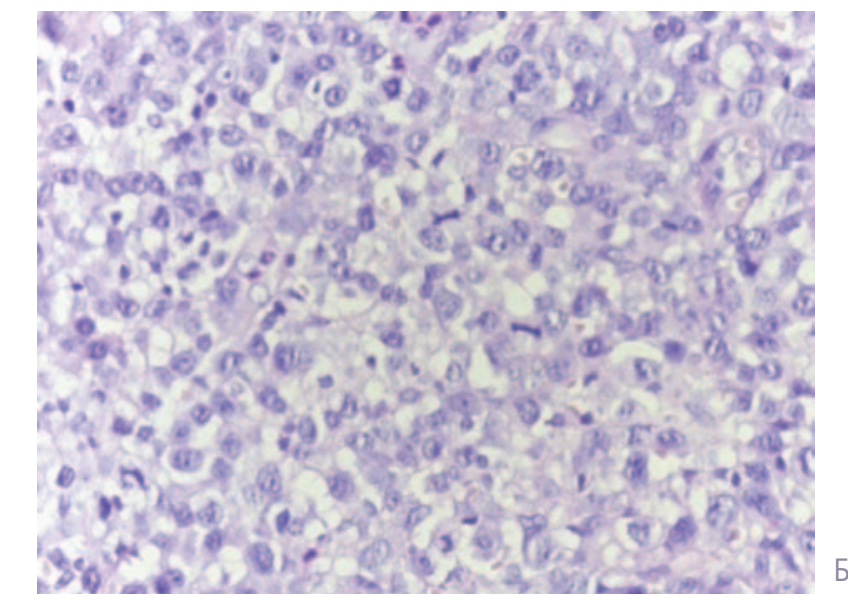

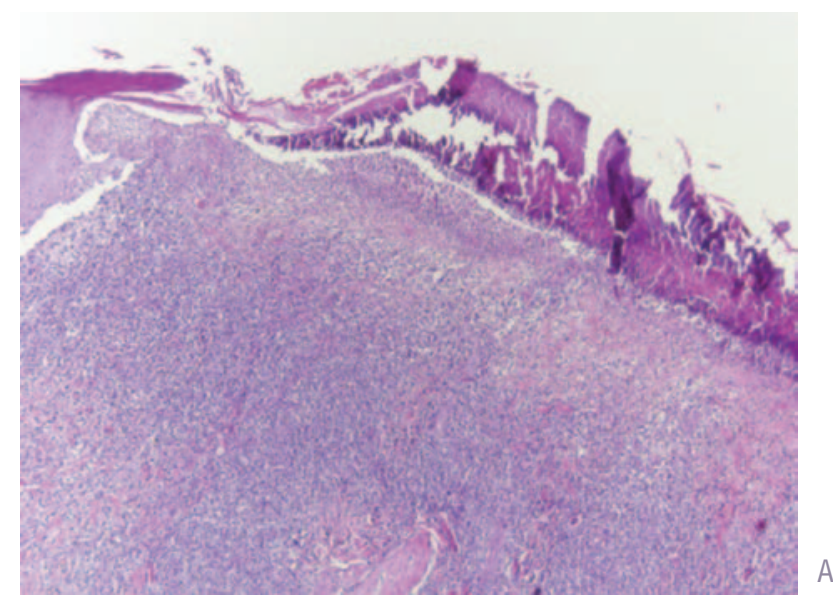



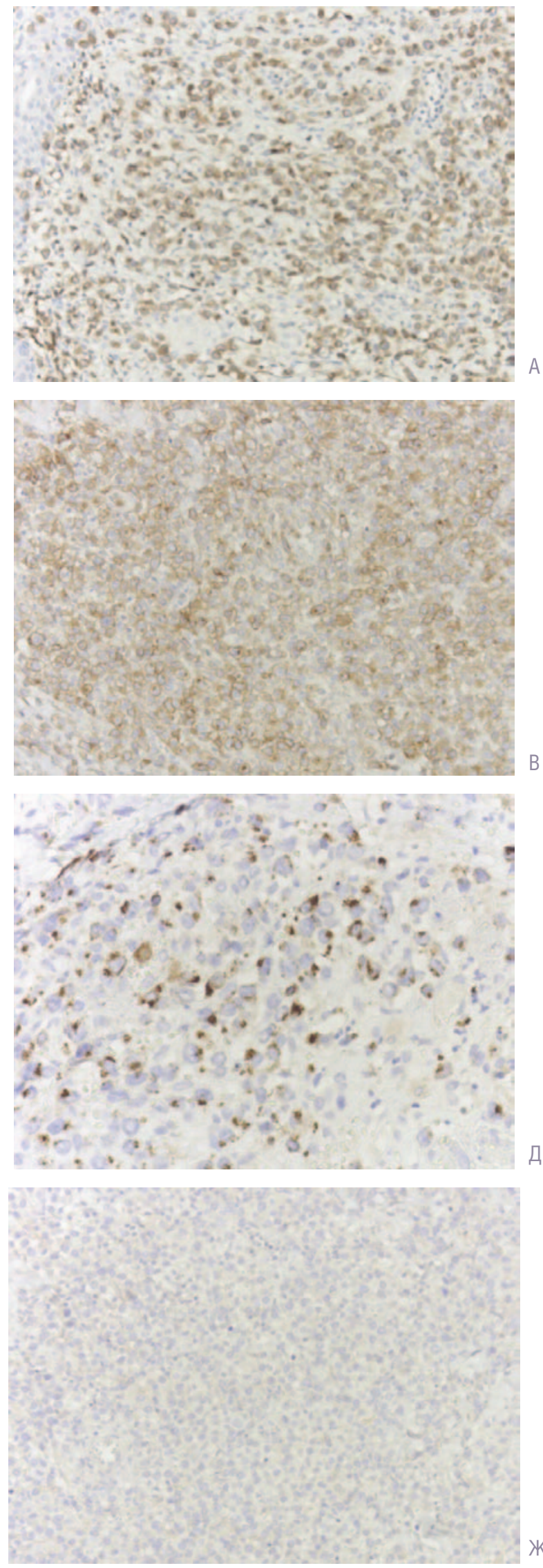
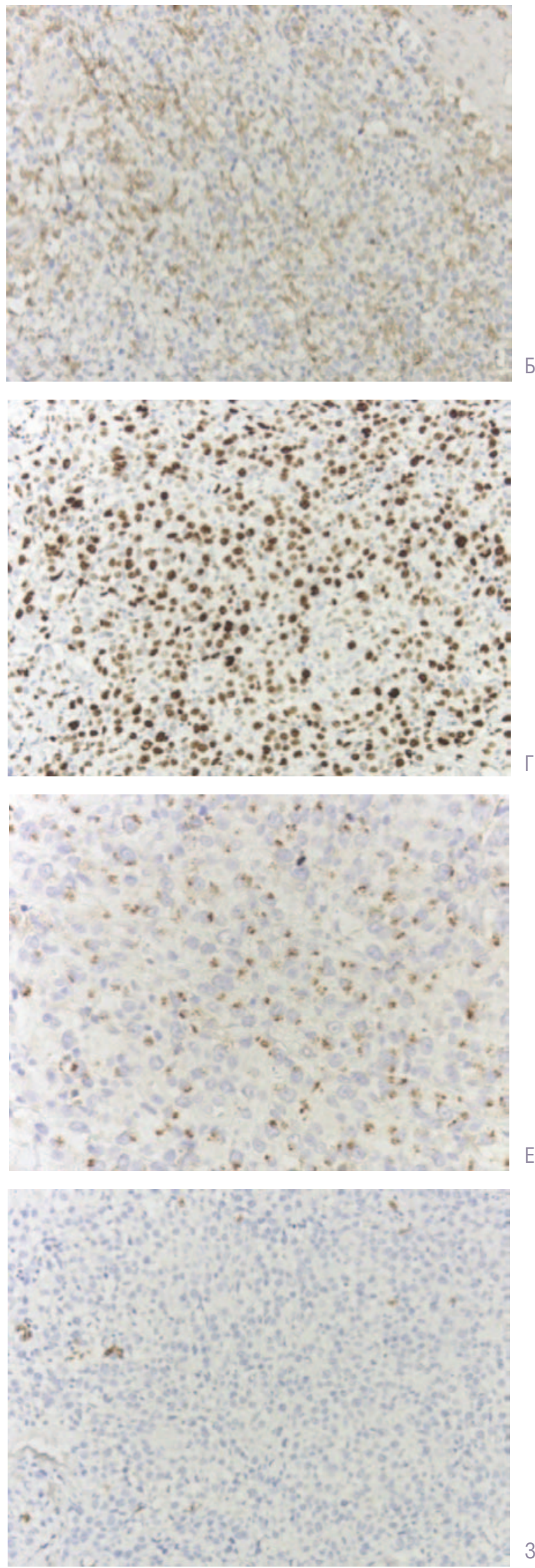

Рис. 3. Иммуногистохимическое исследование биоптата кожи. A — экспрессия CDЗ६, Б — экспрессия CD4, В — экспрессия CD30, Г — пролисееративный индекс Ki67, Д - экспрессия Granzyme B, E - экспрессия TIA-1, Ж — - не экспрессируют ALK, 3 - не экспрессируют CD20

Fig. 3. Immunohistochemical study of skin biopsy specimen. A — CD3 expression, Б — CD4 expression, B — CD30 expression, Г — Ki67 proliferative index, Д — Gran-

zyme B expression, E - TIA-1 expression, $\mathbb{X}$ - ALK does not express, 3 - CD20 does not express 

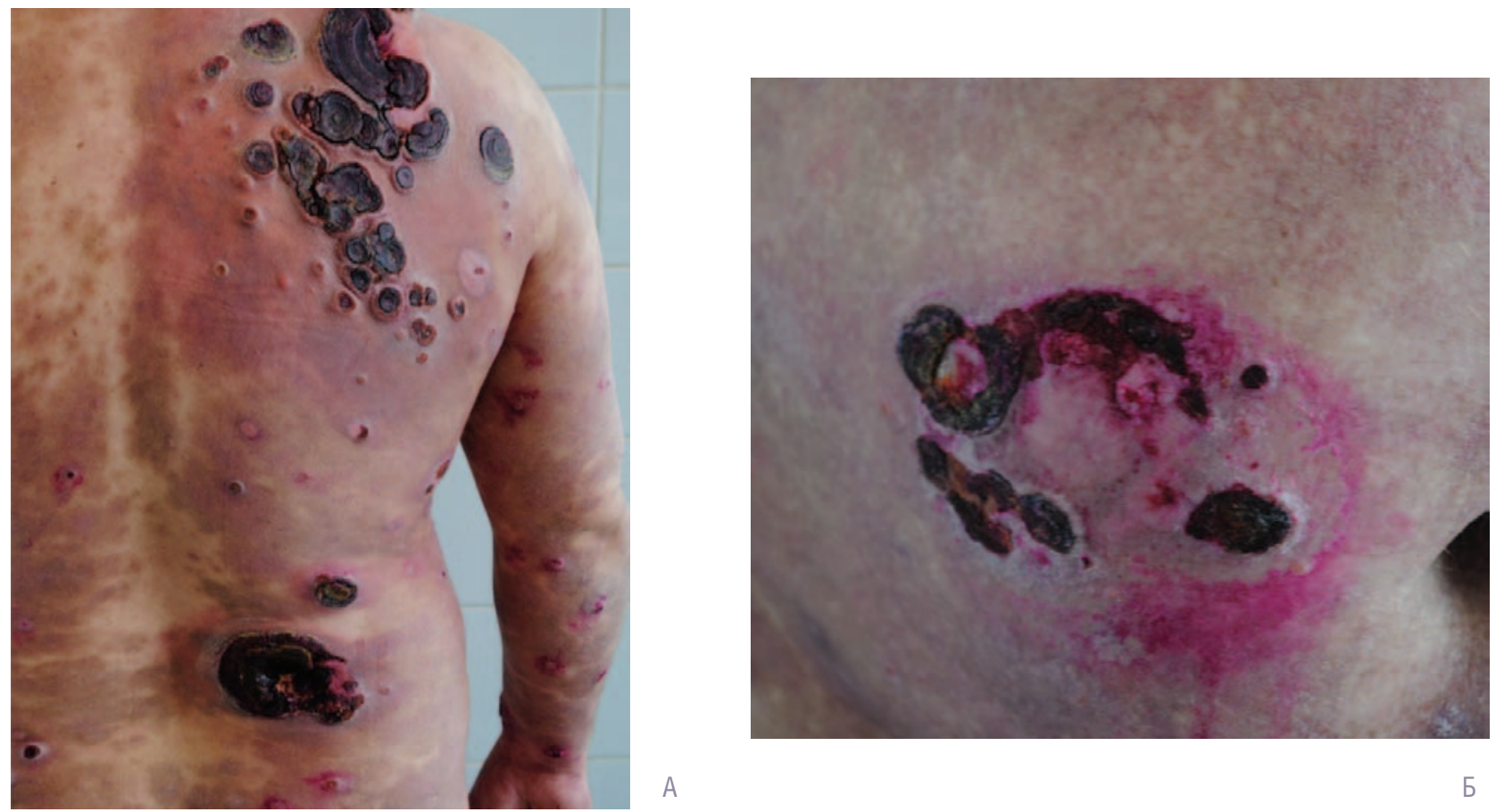

A

| Рис. 4. Динамика клинических проявлений на фоне проводимого лечения в ФГБУ «ГНЦДК» Минздрава России

Fig. 4. Dynamics of clinical manifestations against the background of the treatment carried out in the State Scientific Centre of Dermatovenereology and Cosmetology
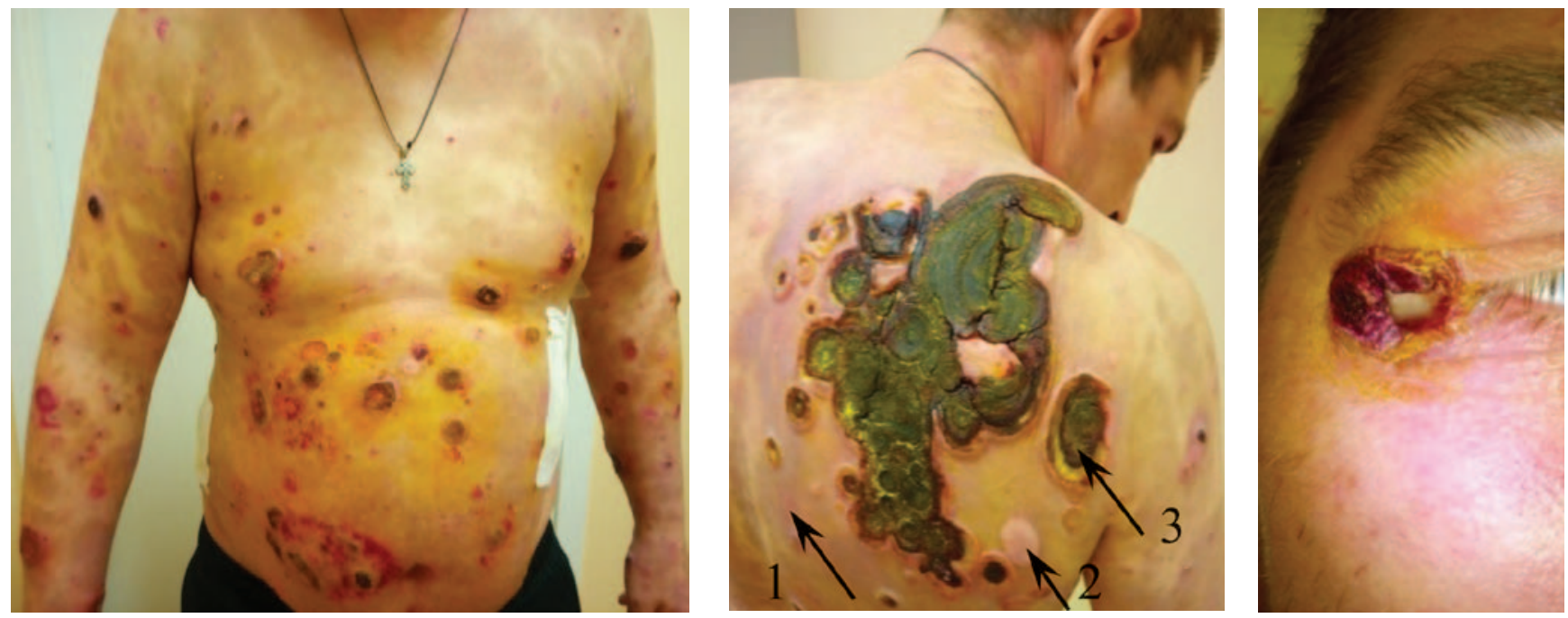

Рис. 5. Клиническая картина при поступлении в ФГБУ «НМИЦ гематологии» Минздрава России. Наблюдалось три типа кожных элементов: гиперпигментированные пятна, обусловленные псориазом (1), бляшки (2), большинство из них с изьязвлением в центре (3)

Fig. 5. The clinical picture of admission to the State Scientific Centre of Dermatovenereology and Cosmetology. Three types of skin elements were observed: hyperpigmented

spots caused by psoriasis (1), plaques (2), most of them with ulceration in the center (3)

Probe (Abbott Laboratories, U.S.A.) транслокация с вовлечением локуса гена ALK/2p23 не выявлена. FISH-исследование с локус-специфичными ДНК-зондами DUSP22/ IRF4 Breakapart Probe/Cen6, TP63 Breakapart/3qtelProbe (Cytocell, UK) не выявило транслокаций с вовлечением локусов генов IRF4/6p25.3, TP63/3q28, однако были выявлены 2-3 дополнительных сигнала от локуса генов IRF4/6p25.3, что свидетельствовало о трисомии и/или тетрасомии хромосомы 6 (рис. 7).

При молекулярно-генетическом исследовании биоптата кожи (тонкая бляшка) была выявлена Т-кле- точная клональность по реаранжировкам генов $ү$-цепи Т-клеточного рецептора. При ПЦР-исследовании биоптата кожи (пятно), образцов перифрерической крови и костного мозга клональной популяции лимфоидных клеток выявлено не было. При исследовании сыворотки крови не было отмечено серологических маркеров активных герпесвирусных инфекций; ДНК вируса Эпштейна - Барр в мононуклеарах периферической крови и пунктате костного мозга не выявлена.

Таким образом, на основании проведенного обследования установлен диагноз первичной кожной анапла- 

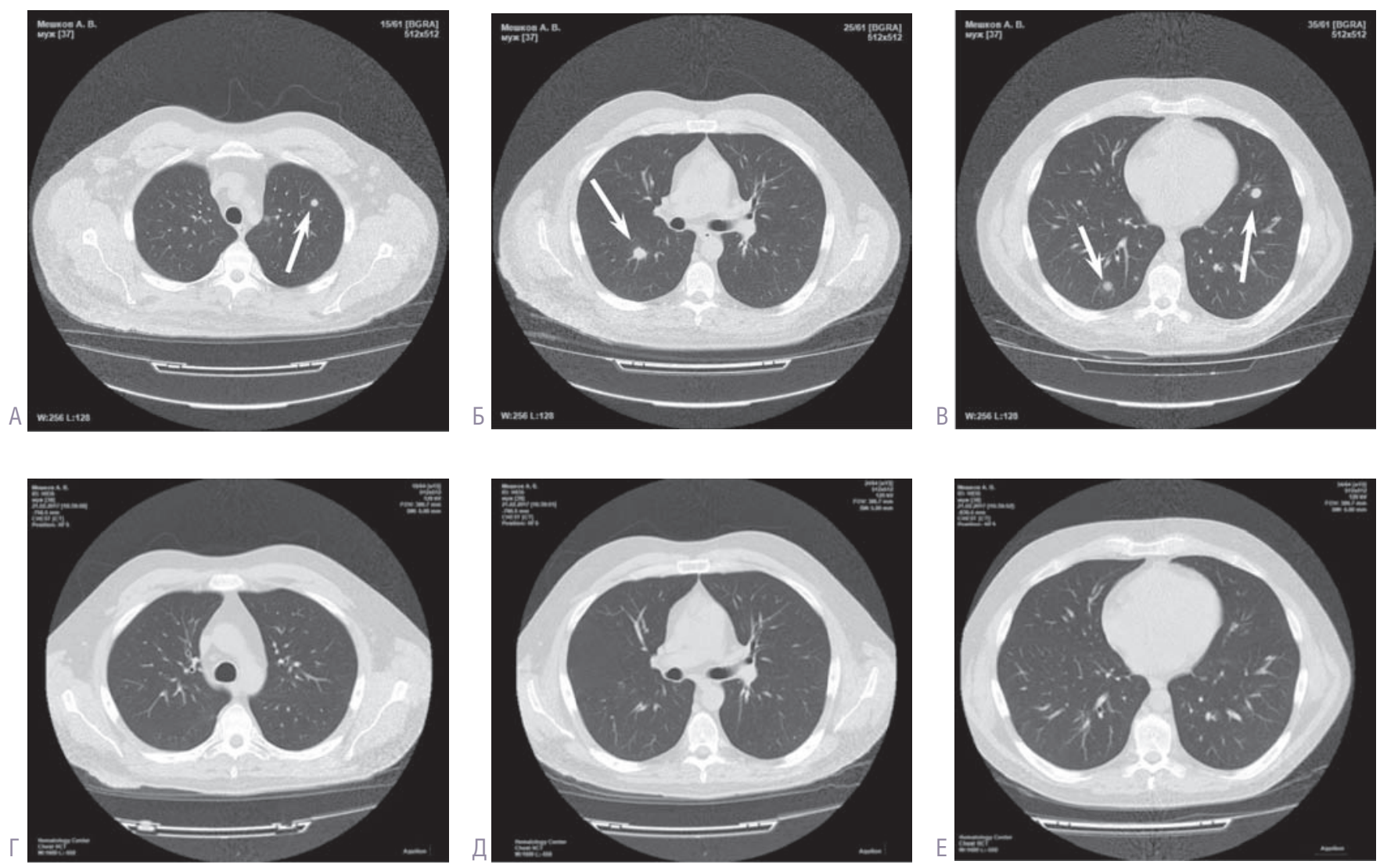

Рис. 6. Множественное очаговое поражение легочной ткани (показано стрелками) по данным мультиспиральной компьютерной томографии органов грудной клетки. A-B - до лечения, Г-E - после лечения

Fig. 6. Multiple focal lesions of the lung tissue (indicated by arrows) according to the multi-spiral computed tomography of the chest. A-B — before treatment,

$\Gamma-\mathrm{E}$ - after treatment

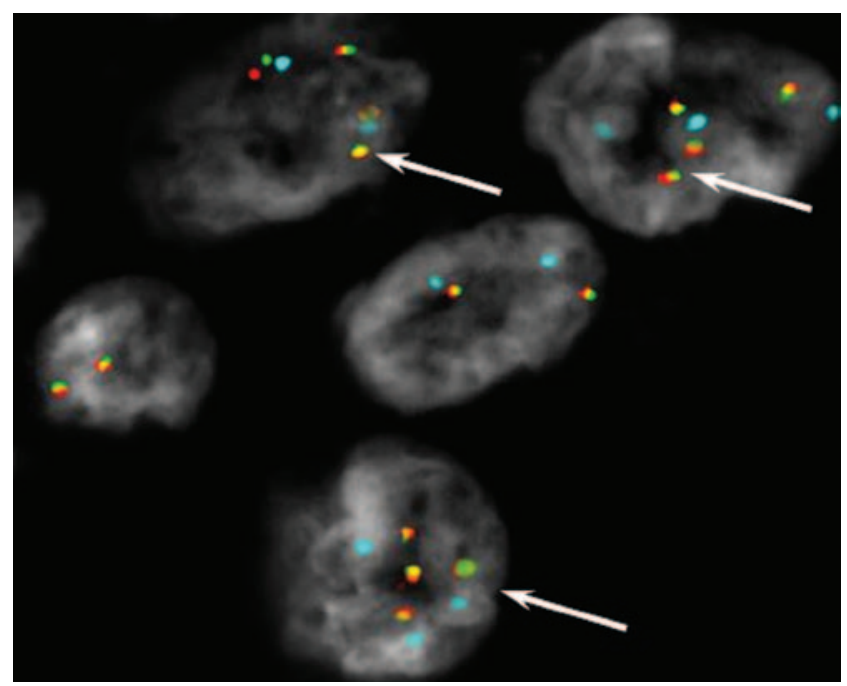

стической крупноклеточной лимфомы с распространенным поражением кожных покровов, подмышечного лимфратического узла справа, изолированным поражением легочной ткани.

В качестве индукционной терапии была выбрана модифицированная программа: дексаметазон, ифросорамид, метотрексат, доксорубицин, винкристин, цитарабин, этопозид, месна, кальция фолинат (NHLBFM-90, блок A) с эскалацией дозы метотрексата до 2 г/M² (табл. 1). Перед началом 1 курса была проведена 5-дневная предфаза, состоящая из ежедневного вну-

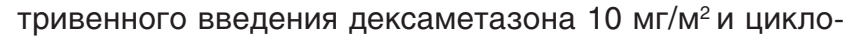
фоссфамида 200 мг/м². Перед каждым курсом химиотерапии проводилась профилактика нейролейкемии, интратекально вводили три цитостатических препарата. Параллельно с курсом цитостатической терапии ежедневно проводилась обработка кожных покровов антисептическими растворами и антибактериальными мазями. Превентивно, до развития миелотоксического агранулоцитоза, выполнено бактериологическое исследование отделяемого с изъязвленной поверхности опухолевых элементов, был выявлен обильный рост Klebsiella pneumonia, продуцирующей $\beta$-лактамазы расширенного спектра действия. Идентифицированный микроорганизм был чувствителен к амикацину, имипенему, колистину и устойчив к меропенему. Посткурсовой период осложнился развитием феебрильной нейтропении и инфекционных осложнений: 
Таблица 1. Схема индукционной химиотерапии по модифицированной программе NHL-BFM-90, блок A

Table 1. The scheme of induction chemotherapy according to the modified NHL-BFM-90 (unit A) program

\begin{tabular}{|c|c|c|c|}
\hline & Препараты & Доза & Дни \\
\hline \multirow{2}{*}{ Предфраза } & Дексаметазон & 10 мг/м² в/в капельно & $1-5$ \\
\hline & Циклофосфамид & 200 мг/м² в/в капельно & $1-5$ \\
\hline \multirow{6}{*}{ Блок А } & Ифосфамид & 800 мг/м² в/в капельно в течение 1 ч & $1-5$ \\
\hline & Метотрексат & 2000 мг/м² в/в капельно в течение 6 ч & 1 \\
\hline & Цитарабин & 150 мг/м² через каждые 12 часов в/в & $4-5$ \\
\hline & Этопозид & 100 мг/м² в/в капельно & $4-5$ \\
\hline & Дексаметазон & 10 мг/м² в/в капельно & $1-5$ \\
\hline & Доксорубицин & 50 мг/м² в/в капельно & 3 \\
\hline
\end{tabular}

орофрарингеального кандидоза, псевдомембранозного колита. Массивная антибиотическая, иноузионная и трансфузионная терапия позволили купировать инфекционные процессы. По завершении первого курса терапии отмечена положительная динамика по основному заболеванию: уменьшение размеров и очищение изъязвленных поверхностей опухолевых элементов, формирование грануляционной ткани; часть небольших опухолевых элементов подверглась полной регрессии, размеры остальных сократились. В зоне максимального опухолевого поражения, в правой плечелопаточной области, из-под струпа прекратилось поступление гнойного отделяемого, края струпа «подсохли», однако его центральная часть продолжала фрлюктуировать. Учитывая выраженную положительную динамику, пациенту была продолжена химиотерапия по той же программе (рис. 8 А). После 2-го курса химиотерапии отмечалась дальнейшая постепенная регрессия опухолевых
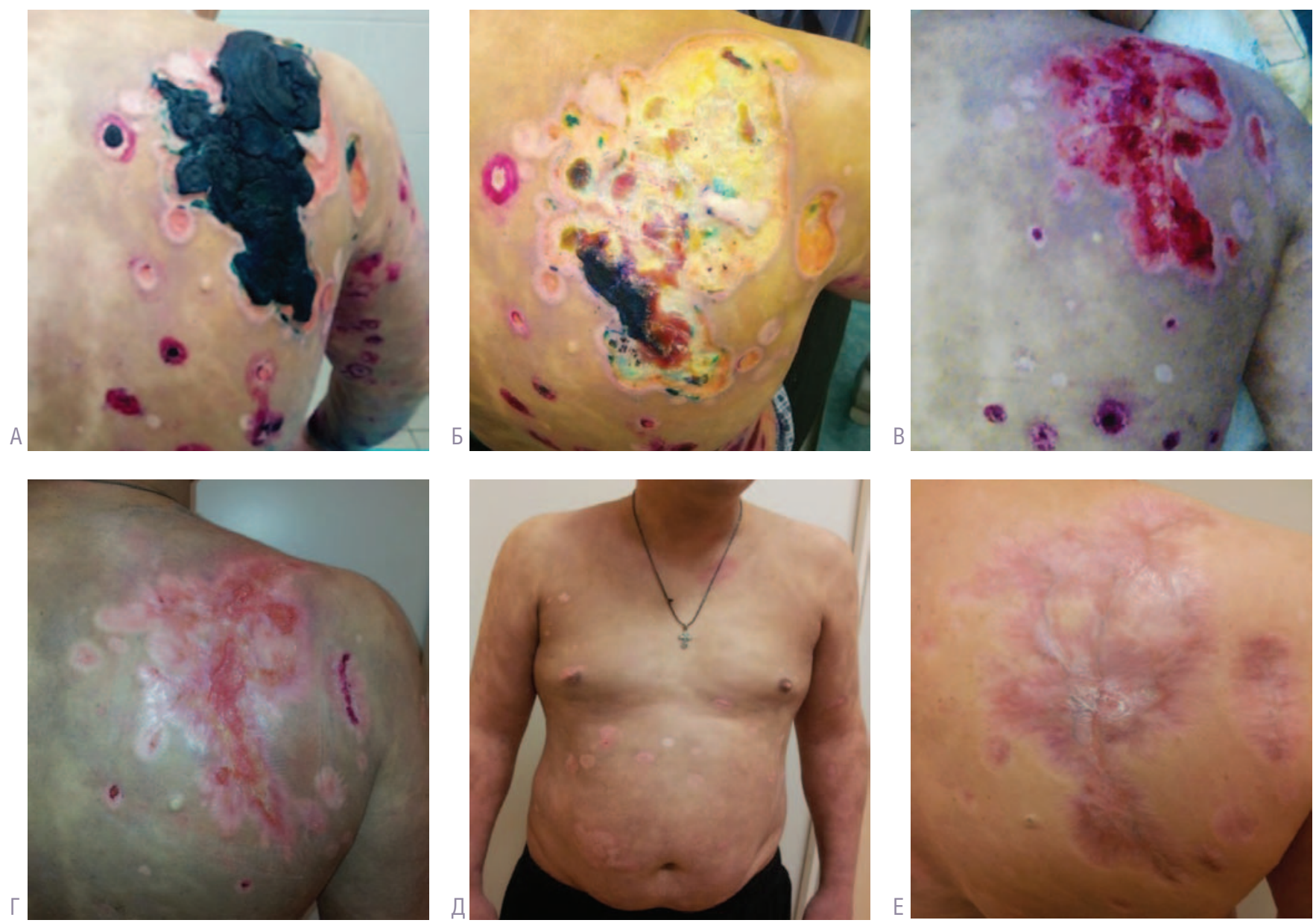

Рис. 8. Динамика кожных элементов больного во время лечения. А — после 1 курса, Б — после 2 курса, В — после высокодозной химиотерапии и аутологичной трансплантации, Г — через 3 месяца после завершения лечения, Д, Е — через 12 месяцев после завершения лечения

Fig. 8. Dynamics of the patient's skin elements during treatment. A — after the 1 st course, $\mathrm{B}$ - after the 2nd course, B — after high-dosage chemotherapy and autologous transplantation, $\Gamma-3$ months after completion of treatment, Д, E - 12 months after the completion of treatment 
элементов на коже. При очередной перевязке самого большого опухолевого элемента в правой плечелопаточной области удалось удалить большую часть струпа (рис. 8Б). При мультиспиральной компьютерной томограсрии органов грудной клетки, проведенной после 2-го курса химиотерапии, была отмечена практически полная регрессия очагов поражения легочной ткани. Учитывая дальнейшую положительную динамику, проведены мобилизация и сбор периферических стволовых клеток крови, суммарно было собрано 5,8 × 106/кг массы тела CD34-позитивных клеток. В последующем проведено еще 2 подобных курса химиотерапии. При контрольном обследовании после завершения индукционной терапии отмечена нормализация размеров аксиллярного лимфатического узла, опухолевые очаги в легочной ткани не определялись (рис. 6 Г-Е). На коже больного отмечалась регрессия большинства очагов опухолевого поражения, однако на месте исходно самых обширных очагов поражения кожи оставались открытые раневые поверхности.

Для консолидации полученного эффректа проведена высокодозная химиотерапия по программе CEAM (ломустин, этопозид, цитарабин, мелфалан) (табл. 2) с последующей трансплантацией гемопоэтических стволовых клеток. Продолжительность миелотоксического агранулоцитоза составила 14 дней, тяжелых инфекционных и токсических осложнений не было отмечено (рис. 8 В). Полная эпителизация раневых поверхностей произошла через 3 месяца после завершения терапии (рис. 8 Г). Позитронно-эмиссионная томограсрия, совмещенная с компьютерной томографией, с 18F-фртордезоксиглюкозой была выполнена через 1,5 месяца после окончания высокодозной терапии, данных о наличии активной опухолевой ткани не было получено. При контрольном обследовании через 6, 12 и 18 месяцев после завершения химиотерапии сохранялась полная ремиссия заболевания (рис. 8 Д, Е).

\section{Обсуждение}

Первичная кожная анапластическая крупноклеточная лимфома является гетерогенной опухолью, которая в большинстве случаев характеризуется благоприятным клиническим течением, отсутствием экстрадермальных очагов поражения [2].

Описанный в статье случай пкАККЛ представлял определенные трудности как при диагностике, так и при выборе тактики лечения. Период от возникновения первого элемента до начала лечения составил 12 месяцев, а от момента первого обращения к врачу по месту жительства до установления диагноза — около 5 месяцев,

Таблица 2. Схема режима кондиционирования СЕАМ

Table 2. The scheme of the CEAM conditioning regimen

\begin{tabular}{|c|c|c|}
\hline Препараты & Доза & Дни \\
\hline Ломустин & 200 мг/м² внутрь & -7 \\
\hline Этопозид & $\begin{array}{c}150 \text { мг/м² через каждые } 12 \text { часов в/в } \\
\text { капельно }\end{array}$ & $-6 \ldots-3$ \\
\hline Цитарабин & $\begin{array}{c}200 \text { мг/м² через каждые } 12 \text { часов в/в } \\
\text { капельно }\end{array}$ & $-6 \ldots-3$ \\
\hline Мелфалан & 140 мг/м² в/в капельно & -2 \\
\hline РеинфузияГСК & в/в струйно & 0 \\
\hline
\end{tabular}

хотя пациент сразу был направлен на биопсию измененного участка кожи. Вероятно, продолжительность периода диагностики была обусловлена нетипичной морфологической картиной заболевания. При гистологическом исследовании первого биоптата изъязвленного участка кожи, выполненном по месту жительства, был установлен диагноз язвенно-гангренозной пиодермии из-за большого количества нейтрофилов. G. Burg и соавт. описали 4 подобных случая пКАККЛ [10], экспрессия опухолевыми клетками интерлейкина 8 способствует привлечению нейтрофилов и эозинофилов, обилие которых симулирует воспаление, маскирует опухолевый процесс под гангренозную пиодермию и затрудняет верификацию лимфомы. На наш взгляд, в подобных ситуациях важным является сопоставление клинико-морфологической картины. При наличии опухолевых элементов с изъязвлением и без такового для биопсии необходимо выбирать опухолевый элемент без изъязвления, а также не пренебрегать проведением иммуногистохимического, молекулярного и цитогенетического исследований.

Следующим важным этапом в диагностике пкАККЛ у этого больного было разграничение пкАККЛ от крупноклеточной трансорормации грибовидного микоза, а также от вторичного поражения кожи при нодальной AKKЛ, ALK-. В зарубежной литературе представлены случаи грибовидного микоза, протекающего с нетипичной клинической картиной, имитирующей обычный псориаз [29], а экстранодальное поражение, в том числе вовлечение кожи, нередко наблюдается при нодальной AKKЛ, ALK- [2]. Учитывая наличие множественных гиперпигментированных пятен у больного, а также документально не подтвержденный псориаз в анамнезе, для исключения крупноклеточной трансформации грибовидного микоза была проведена биопсия участка кожи (пятно). При гистологическом и молекулярном исследованиях данных за опухолевый процесс получено не было. По данным первичного обследования (МСКТ органов грудной клетки, УЗИ брюшной полости и периферических лимфатических узлов) выявлено вовлечение единственного регионарного лимфатического узла в зоне максимального опухолевого поражения, что более характерно для пкАКKЛ, чем нодальной AKKЛ, ALK[2]. Поскольку биопсия подмышечного лимфратического узла не проводилась, невозможно категорично утверждать о его опухолевом поражении, возможно, увеличение размеров лимфатического узла было связано с реактивными изменениями из-за массивного инфекционного процесса, сопровождающего опухоль.

Интересная находка - очаговое опухолевое поражение легочной ткани. В зарубежной литературе присутствует описание единичных случаев поражения легочной ткани при пкАККЛ. В исследовании S. Baseretal [30] опухолевое поражение легочной ткани было отмечено у 6 из 710 пациентов с Т-клеточными лимфомами кожи и ассоциировано с неблагоприятным прогнозом.

При цитогенетическом исследовании биоптата опухолевого элемента кожи не была выявлена реаранжировка локуса IRF4-DUSP22 на 6p25.3, ассоциированная с благоприятным клиническим течением, но в то же время не были обнаружены транслокации с вовлечением локуса гена TP63 и делеции 6q21 и 18p11.3, наблюдающиеся при агрессивном клиническом и рецидивирующем течении заболевания [17-21]. 
При выборе тактики лечения пациента мы руководствовались распространенным поражением кожных покровов, в том числе кожи нижних конечностей, вовлечением легочной ткани и прогрессированием опухолевого процесса на терапии малыми дозами метотрексата. Опираясь на собственный опыт, для лечения этого больного была выбрана модифицированная программа NHL-BFM-90, блок A, успешно применяемая для лечения агрессивных В- и Т-клеточных лимфом в ФГБУ «НМИЦ гематологии» Минздрава России [31, 32]. Эта программа содержит кроме препаратов, входящих в курс CHOP, цитарабин, этопозид и метотрексат. Выбранная тактика лечения больного позволила достигнуть полной ремиссии заболевания, подтвержденной ПЭТ-КТ с 18F-ФДГ, продолжительностью на момент написания статьи 18 мес.

Однако проведение интенсивной индукционной терапии при наличии множественных очагов изъязвления кожных покровов при выделении в посевах с раневой поверхности Klebsiella pneumoniae, устойчивой к большинству антибактериальных препаратов, крайне затруднительно, но может быть реализовано при воз- можности проведения соответствующей антибиотической и трансфузионной терапии. По нашему мнению, в подобных ситуациях было бы целесообразным проведение на первом этапе лечения нескольких введений брентуксимаб ведотина, который бы позволил сократить массу опухоли и уменьшить площадь раневых поверхностей без значительной лейкопении и развития инфекционных осложнений.

\section{Заключение}

В статье представлен успешный опыт взаимодействия дерматологов, гематологов и патоморфологов в диагностике и лечении первичной кожной анапластической крупноклеточной лимфомы с распространенным поражением кожного покрова, вовлечением легочной ткани. Для лечения больного была применена интенсивная индукционная терапия с последующей высокодозной консолидацией и аутологичной трансплантацией гемопоэтических стволовых клеток. Выбранная тактика лечения позволила достигнуть продолжительной полной ремиссии заболевания у больного с неблагоприятными фракторами прогноза.

\section{Литература/References}

1. Vose J., Armitage J., Weisenburger D. International peripheral T-cell and natural killer / T-cell lymphoma study: pathology findings and clinical outcomes. International T-Cell Lymphoma Project. J Clin Oncol. 2008 Sep 1;26(25):4124-4130. DOI: 10.1200/JC0.2008.16.4558

2. Swerdlow S. H., Campo E., Harris N. L., Jaffe E. S., Pileri S. A., Stein H., Thiele J., Arber D. A., Hasserjian R. P., Le Beau M. M., Orazi A., Siebert R. WHO classification of tumors of haematopoietic and lymphoid tissues. Lyon: IARC, 2017:395-396.

3. Kadin M. E., Carpenter C. Systemic and primary cutaneous anaplastic large cell lymphomas. Semin Hematol. 2003;40(3):244-256.

4. Bekkenk M. W., Geelen F. A., van Voorst Vader P. C., Heule F., Geerts M. L., van Vloten W. A., Meijer C. J., Willemze R. Primary and secondary cutaneous $\mathrm{CD} 30(+)$ lymphoproliferative disorders: a report from the Dutch Cutaneous Lymphoma Group on the long-term follow-up data of 219 patients and guidelines for diagnosis and treatment. Blood. 2000;95(12):3653-3661.

5. Stein H., Foss H. D., Dürkop H., Marafioti T., Delsol G., Pulford K., Pileri S., Falini B. CD30(+) anaplastic large cell lymphoma: a review of its histopathologic, genetic, and clinical features. Blood. 2000;96(12):3681-3695.

6. Paulli M., Berti E., Rosso R., Boveri E., Kindl S., Klersy C., Lazzarino M., Borroni G., Menestrina F., Santucci M. et al. CD30/Ki-1-positive lymphoproliferative disorders of the skin - clinicopathologic correlation and statistical analysis of 86 cases: a multicentric study from the European Organization for Research and Treatment of Cancer Cutaneous Lymphoma Project Group. J Clin Oncol. 1995;13(6):1343-1354. D0I: 10.1200/ JC0.1995.13.6.1343

7. Kempf W., Pfaltz K., Vermeer M. H., Cozzio A., Ortiz-Romero P. L., Bagot M. et al. EORTC, ISCL, and USCLC consensus recommendations for the treatment of primary cutaneous CD30-positive lymphoproliferative disorders: Iymphomatoid papulosis and primary cutaneous anaplastic large-cell lymphoma. Blood. 2011;118(15):4024-4035. DOI: 10.1182/ blood-2011-05-351346
8. Willemze R., Jaffe E. S., Burg G., Cerroni L., Berti E., Swerdlow S. H. et al. WHO-EORTC classification for cutaneous lymphomas. Blood. 2005;105(10):3768-3785.

9. Dogan A., Morice W. G. Bone marrow histopathology in peripheral T-cell lymphomas. Br J Haematol. 2004;127(2):140-154. DOI: 10.1111/j.1365-2141.2004.05144.x

10. Burg G., Kempf W., Kazakov D. V., Dummer R., Frosch P. J., Lange-lonescu S., Nishikawa T., Kadin M. E. Pyogenic Iymphoma of the skin: a peculiar variant of primary cutaneous neutrophil-rich CD30+ anaplastic large-cell lymphoma. Clinicopathological study of four cases and review of the literature. Br J Dermatol. 2003;148(3):580-586.

11. Felgar R. E., Macon W. R., Kinney M. C., Roberts S., Pasha T., Salhany K. E. TIA-1 expression in lymphoid neoplasms. Identification of subsets with cytotoxic T lymphocyte or natural killer cell differentiation. Am J Pathol. 1997;150(6):1893-1900.

12. Boulland M. L., Wechsler J., Bagot M., Pulford K., Kanavaros P., Gaulard P. Primary CD30-positive cutaneous T-cell lymphomas and lymphomatoid papulosis frequently express cytotoxic proteins. Histopathology. 2000;36(2):136-144.

13. Молочков А. В., Ковригина А. М., Кильдюшевский А. В., Караулов А. В. Лимсомы кожи. М.: Бином, 2012:44-46. [Molochkov A. V., Kovrigina A. M., Kildyushevsky A. V., Karaulov A. V. Skin Lymphoma. Moscow: Binom, 2012:44-46. (In Russ.)].

14. Macgrogan G., Vergier B., Dubus P., Beylot-Barry M., Belleannee G., Delaunay M. M., Eghbali H., Beylot C., Rivel J., Trojani M., Vital C., DeMascarel A., Bloch B., Merlio J. P. CD30-positive cutaneous large cell lymphomas. A comparative study of clinic pathologic and molecular features of 16 cases. Am J Clin Pathol. 1996;105(4):440-450.

15. Laharanne E., Oumouhou N., Bonnet F., Carlotti M., Gentil C., Chevret E., Jouary T., Longy M., Vergier B., Beylot-Barry M., Merlio J. P. Genome-wide analysis of cutaneous T-cell lymphomas identifies three clinically relevant classes. J Invest Dermatol. 2010;130(2):563-575. DOl: 10.1038/jid.2009.270 
16. van Kester M. S., Tensen C. P., Vermeer M. H., Dijkman R., Mulder A. A., Szuhai K., Willemze R., van Doorn R. Cutaneous anaplastic large cell lymphoma and peripheral T-cell lymphoma NOS show distinct chromosomal alterations and differential expression of chemokine receptors and apoptosis regulators. J Invest Dermatol. 2010;130(6):1707-1718. D0I: 10.1038/jid.2010.8

17. Wada D. A., Law M. E., Hsi E. D., Dicaudo D. J., Ma L., Lim M. S. et al. Specificity of IRF4 translocations for primary cutaneous anaplastic large cell lymphoma: a multicenter study of 204 skin biopsies. Mod Pathol. 2011;24(4):596-605. D0l: 10.1038/modpathol.2010.225

18. Pham-Ledard A., Prochazkova-Carlotti M., Laharanne E., Vergier B., Jouary T., Beylot-Barry M., Merlio J. P. IRF4 gene rearrangements define a subgroup of CD30-positive cutaneous T-cell lymphoma: a study of 54 cases. J Invest Dermatol. 2010;130(3):816-825. D0l: 10.1038/jid.2009.314

19. Vasmatzis G., Johnson S. H., Knudson R. A., Ketterling R. P., Braggio E., Fonseca R. et al. Genome-wide analysis reveals recurrent structural abnormalities of TP63 and other p53-related genes in peripheral T-cell lymphomas. Blood. 2012;120(11):2280-2289. DOI: 10.1182/ blood-2012-03-419937

20. Parrilla Castellar E. R., Jaffe E. S., Said J. W., Swerdlow S. H., Ketterling R. P., Knudson R. A. et al. ALK-negative anaplastic large cell lymphoma is a genetically heterogeneous disease with widely disparate clinical outcomes. Blood 2014;124(9):1473-1480. DOl: 10.1182/ blood-2014-04-571091

21. Prochazkova M., Chevret E., Beylot-Barry M., Sobotka J., Vergier B., Delaunay M., Turmo M., Ferrer J., Kuglik P., Merlio J. P. Chromosomal imbalances: a hallmark of tumour relapse in primary cutaneous CD30+ T-cell Iymphoma. J Pathol. 2003;201(3):421-429. D0I: 10.1002/path.1469

22. Younes A., Bartlett N. L., Leonard J. P., Kennedy D. A., Lynch C. M., Sievers E. L., Forero-Torres A. Brentuximab vedotin (SGN-35) for relapsed CD30-positive lymphomas. N Engl J Med. 2010;363(19):18121821. DOI: 10.1056/NEJMoa1002965

23. Pro B., Advani R., Brice P., Bartlett N. L., Rosenblatt J. D., IIlidge T., Matous J., Ramchandren R., Fanale M., Connors J. M., Fenton K., Huebner D., Pinelli J. M., Kennedy D. A., Shustov A. Five-year results of brentuximab vedotin in patients with relapsed or refractory systemic anaplastic large cell lymphoma. Blood. 2017;130(25):2709-2717. DOI: 10.1182/blood-2017-05-780049

24. Duvic M., Reddy S. A., Pinter-Brown L., Korman N. J., Zic J., Kennedy D. A., Lorenz J., Sievers E. L., Kim Y. H. A phase II study of SGN-30 in cutaneous anaplastic large cell lymphoma and related lymphoproliferative disorders. Clin Cancer Res. 2009 0ct 1;15(19):6217-6224. DOI: 10.1158/1078-0432.CCR-09-0162
25. Liu H. L., Hoppe R. T., Kohler S., Harvell J. D., Reddy S., Kim Y. H. CD30+ cutaneous lymphoproliferative disorders: the Stanford experience in lymphomatoid papulosis and primary cutaneous anaplastic large cell lymphoma. J Am Acad Dermatol. 2003;49(6):1049-1058. DOl: $10.1016 /$ S0190

26. Benner M. F., Willemze R. Applicability and prognostic value of the new TNM classification system in 135 patients with primary cutaneous anaplastic large cell lymphoma. Arch Dermatol. 2009;145(12):1399-1404. DOI: 10.1001/archdermatol.2009.280

27. Woo D. K., Jones C. R., Vanoli-Storz M. N., Kohler S., Reddy S., Advani R., Hoppe R. T., Kim Y. H. Prognostic factors in primary cutaneous anaplastic large cell lymphoma: characterization of clinical subset with worse outcome. Arch Dermatol. 2009;145(6):667-674. D0l: 10.1001/archdermatol.2009.74

28. Hapgood G., Pickles T., Sehn L. H., Villa D., Klasa R., Scott D. W., Gerrie A. S., Gascoyne R. D., Slack G. W., Parsons C., Morris J. W., Connors J. M., Savage K. J. Outcome of primary cutaneous anaplastic large cell Iymphoma: a 20-year British Columbia Cancer Agency experience. Br J Haematol. 2017;176(2):234-240. DOl: 10.1111/bjh.14404

29. Doukaki S., Aricò M., Bongiorno MR.A Rare Presentation of Mycosis Fungoides Mimicking Psoriasis Vulgaris. Case Rep Dermatol. 2009;1(1):60-65. DOI: 10.1159/000249148

30. Baser S., Onn A., Lin E., Morice R. C., Duvic M. Pulmonary manifestations in patients with cutaneous T-cell lymphomas. Cancer. 2007;109(8):1550-1555. DOI: 10.1002/cncr.22567

31. Савченко В. Г. (ред.) Алгоритмы диагностики и протоколы лечения заболеваний системы крови. М.: Практика, 2018. Т. 2. [Savchenko V. G. (ed.) Diagnostic algorithms and protocols for the treatment of diseases of the blood system. Moscow: Praktika, 2018. V. 2. (In Russ.)]

32. Чернова Н. Г., Звонков Е. Е., Бадмажапова Д. С., Синицына М. Н., Гребенюк Л. А., Сидорова Ю. В., Костина И. Э., Ковригина А. М., Обухова Т. Н., Судариков А. Б., Савченко В. Г. Первый опыт применения комбинации брентуксимаба ведотина с интенсивной химиотерапией у первичной больной анапластической крупноклеточной лимсомой: обзор литературы и описание клинического случая. Терапевтический архив. 2018;90(7):77-81. [Chernova N. G., Zvonkov E. E., Badmazhapova D. S., Sinitsyna M. N., Grebenyuk L. A., Sidorova Y. V., Kostina I. E., Kovrigina A. M., Obukhova T. N., Sudarikov A. B., Savchenko V. G. First experience of using Brentuximabvedotin and modified program NHL-BFM-90 in the front-line treatment of patient with anaplastic large-cell lymphoma: a case report and a review of literature. Terapevticheskij Arhiv. 2018;90(7):33-37 (In Russ.)]

\section{Информация об авторах}

Наталья Геннадьевна Чернова* - к.м.н., врач-гематолог Национального медицинского исследовательского центра гематологии Министерства здравоохранения Российской Федерации; e-mail: ngchernova@mail.ru

Дарима Сэмункоевна Бадмажапова - аспирант Национального медицинского исследовательского центра гематологии Министерства здравоохранения Российской Федерации; e-mail: darima-doctor@mail.ru

Алла Михайловна Ковригина - д.б.н., заведующая лабораторией Национального медицинского исследовательского центра гематологии Министерства здравоохранения Российской Федерации; e-mail: kovrigina.alla@gmail.com

Арфеня Эдуардовна Карамова - к.м.Н., заведующая отделом дерматологии Государственного научного центра дерматовенерологии и косметологии Министерства здравоохранения Российской Федерации; e-mail: karamova@cnikvi.ru

Анастасия Александровна Воронцова - младший научный сотрудник отдела дерматологии Государственного научного центра дерматовенерологии и косметологии Министерства здравоохранения Российской Федерации; e-mail: nastasia08@bk.ru 
Марина Николаевна Синицына - научный сотрудник Национального медицинского исследовательского центра гематологии Министерства здравоохранения Российской Федерации; е-mail: msini@mail.ru

Юлия Владимировна Сидорова - к.м.Н., старший научный сотрудник Национального медицинского исследовательского центра гематологии Министерства здравоохранения Российской Федерации; e-mail: iouliavl@rambler.ru

Любовь Алексеевна Гребенюк - ведущий специалист по молекулярной биологии Национального медицинского исследовательского центра гематологии Министерства здравоохранения Российской Федерации; e-mail: Iyuba.grebenyuk@yandex.ru

Мария Андреевна Нефедова - младший научный сотрудник отдела дерматологии Государственного научного центра дерматовенерологии и косметологии Министерства здравоохранения Российской Федерации; e-mail: nefedova.maria.arb@gmail.com

Людмила Федоровна Знаменская - д.м.н., ведущий научный сотрудник отдела дерматологии Государственного научного центра дерматовенерологии и косметологии Министерства здравоохранения Российской Федерации; e-mail:znaml@cnikvi.ru

Евгений Евгеньевич Звонков - д.м.Н., заведующий отделением Национального медицинского исследовательского центра гематологии Министерства здравоохранения Российской Федерации; e-mail: dr.zvonkov@gmail.com

Валерий Григорьевич Савченко - генеральный директор Национального медицинского исследовательского центра гематологии Министерства здравоохранения Российской Федерации, академик РАН; e-mail: director@blood.ru

\section{Information about the authors}

Natalia G. Chernova* — Cand. Sci. (Med.), Hematologist Doctor, National Research Center for Hematology; e-mail: ngchernova@mail.ru

Darima S. Badmazhapova — Post-Graduate Student, National Research Center for Hematology; e-mail: darima-doctor@mail.ru

Alla M. Kovrigina - Dr. Sci. (Biol.), Laboratory Head, National Research Center for Hematology; e-mail: kovrigina.alla@gmail.com

Arfenya E. Karamova - Cand. Sci. (Med.), Departmental Head, Department of Dermatology, State Scientific Center of Dermatovenereology and Cosmetology; e-mail: karamova@cnikvi.ru

Anastasia A. Vorontsova - Junior Researcher, Department of Dermatology, State Scientific Center of Dermatovenereology and Cosmetology; e-mail: nastasia08@bk.ru

Marina N. Sinitcina — Researcher, National Research Center for Hematology; e-mail: msini@mail.ru

Yulia V. Sidorova - Cand. Sci. (Med.), Senior Researcher, National Research Center for Hematology; e-mail: iouliavl@rambler.ru

Lyubov A. Grebenyuk — Leading Molecular Biology Specialist, National Research Center for Hematology; e-mail: Iyuba.grebenyuk@ yandex.ru

Maria A. Nefedova - Junior Researcher, Dapartment of Dermatology, State Scientific Center of Dermatovenereology and Cosmetology; e-mail: nefedova.maria.arb@gmail.com

Ludmila F. Znamenskaya - Dr. Sci. (Med.), Leading Researcher, Department of Dermatology, State Scientific Center of Dermatovenereology and Cosmetology; e-mail:znaml@cnikvi.ru

Evheny E. Zvonkov — Dr. Sci. (Med.), Departmental Head, National Research Center for Hematology; e-mail: dr.zvonkov@gmail.com

Valery G. Savchenko — RAS Academician, General Director, National Research Center for Hematology; e-mail: director@blood.ru 